\section{クラフ活娌を視定するクラフ 整の分析}

\section{一特にハくスケット部を中心に一}

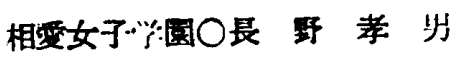
大阪学芸大学 更 田 為司

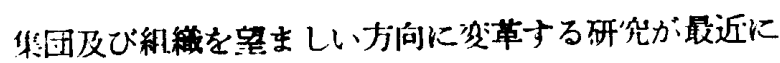
なつて大きく取扱われるようになつてきた。しかし、こ の場合の望ましいといらことは，心理学的な立場から種 々な条件が考えられる。特体青科を担当する私として は、フクション・リサーチの一つの試みとして，望まし いクラブへの䖽行を検討しようとするものである，われ われの研究する対象が理動競技に関俰するクラブであれ ば，最も效率の常いクラブといらためには対戦毎に勝利 を收め，競技猧程においてもそのミスする比率が少ない ということが必要とせられるが，教育的立場からクラブ 活動の人格形成に大きな意義をみつけ，学校教有という 枠組の中でクラブ棰造の变革をとりあげることにする：

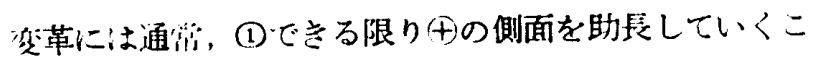
上，(2)できる限りもの側面を除去していく方向があつ て、本研究もクラブ内部のӨの傾としてどのような規 潗を設定することができ，そのӨから生起する諸々の葛 藤上どのような対応関俰があるのかを理解しなければな らない，そのため，認知的次元として，(1) 対人関保 の好意性，(1) クラブ活動で行う運動種目に対寸る誇 り，(田）自分の所属するクラブのブレステイージにつ いて，(N) 白分のクラブにおける 集団生活に対する魅 力（V）そのクラプに所属することによりどのような 利益が得られるか（视）また一旦入部したクラブから 容易に退部できない拘束性がどんなであるのか，以上を

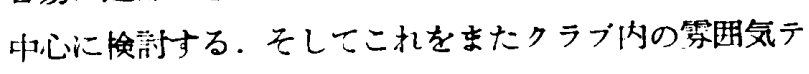
ストとの関係をみた。本研究で使用した測定法は，（I） クラブ活動の関心度を测定する尺度，(1）クラプにつ いての雾囲気テストでいすれも5-point の重みつけに より集計した，研究対象は，相爱女子学園の高校生を中 心とするパスケット部員 $(\mathbf{N}=11$, 実験群)，テニス部員 $(N=13)$ ）ソフトポール部員 $(N=6)$ ，スケート部員 $(N=9)$, 卓球部員 $(N=11)$ である.クラブ活動の関心 度におい、 $\mathrm{B}_{\mathbf{0}}$ (バスケット部貝の被験者番号) が，60 〜シCOに分布する中てに点の最高で， $\mathrm{B}_{4}$ が 200 点の

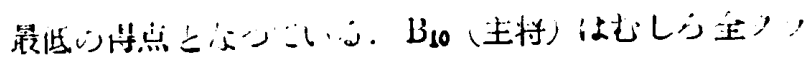

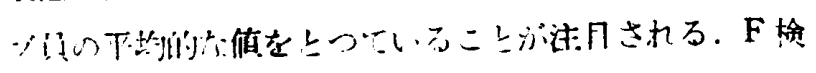

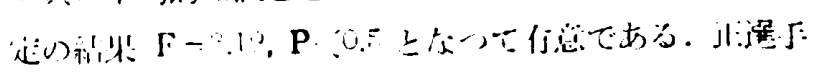
$\left(\mathrm{B}_{1}, \mathrm{~B}_{2}, \mathrm{~B}_{6}, \mathrm{~B}_{7}, \mathrm{~B}_{9}, \mathrm{~B}_{10}, \mathrm{~B}_{11}\right)$ 上補欠資手 $\left(\mathrm{B}_{3}, \mathrm{~B}_{4}, \mathrm{~B}_{6}\right.$,

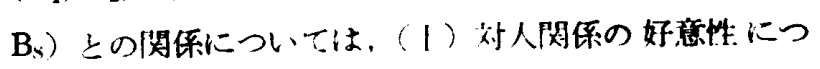
いては，正䢒手の方が高いこと，50点中（正の平均値 40.4, 補 37.5)，(1) 渾動種目に対与る誇りについては, 正選手の方が同じく高く（正 35.5，補 33.2），(I）クラ ブのプレスティージにつては，むしろ補久選手のカが

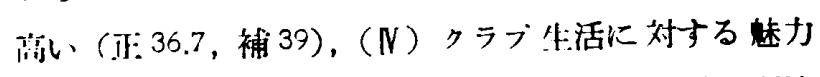

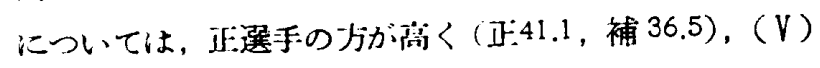
クラプの利益性については正選手の方が高く（正 39.5, 補 37）となり，(N) クラプの拘束性については，補欠 選手の方が高かつた（正 33，補 34.2)。全体としては有 意な結果はみられなかつたが $\left(\chi^{2}=0.16, \mathrm{df}=5\right)$, 特に （1）と（N）について $5 \%$ 水準で有意であつた，雾

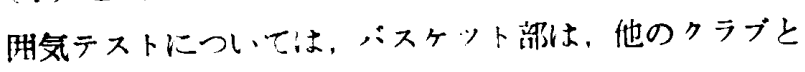
比較してそれほど得点の分散が違わないか，快央倠より 望をしい力问にあつた。

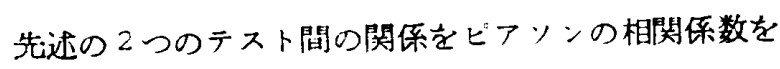
バスケット部たけに限定してみると、雾囲気テスト(M) と第|の対人関係の好意度との関係 $\mathrm{r}=0.46, \mathrm{M}$ と第 | の運動種目に対寸る誇りとの関係 $\mathrm{r}=0.00, \mathrm{M}$ と第】の クラプのプレステイージとの関釈は, $\mathrm{r}=0.56, \mathrm{M}$ と第 Nの集団生活に対寸る魅力との関俰は $\mathrm{r}=0.58$. M と第 Vのクラプの利益性との関俰は， $\mathrm{r}=0.22$ となり, $\mathrm{M}$ と 第川のクラプの拘束性との関俰は $\mathrm{r}=0.49$ となつてい る.以上の相関関係からいえることは，非常にクラプの 零用気といら現象は，クシブ活動の指翼に重要な圙と なることはいうまでもないが、これらはクラプ員相互の 对人関係における好意性の程度によりまた自分のクラプ については他のクラブよりもすばらしいのたよいつたプ レスティージにより，さらには個々のクラブ員が積極的 に慗団生活をしたいといら態度によつて支えられている 場合、またこれは今啳の課遉の一つでああるが，クラブ を簢単に入部したり，退部したりできない拘束性上いう 力によつてある程度支配されるとす理解された。 